\title{
PENGARUH PENERAPAN ISO 9001:2008 TERHADAP KUALITAS PRODUK PADA DEPARTEMEN PRODUKSI PT FUTAMI FOOD\&BEVERAGES BOGOR
}

\author{
THE EFFECT OF IMPLEMENTING ISO 9001: 2008 ON THE QUALITY OF \\ PRODUCTS IN THE PRODUCTION DEPARTMENT OF PT FUTAMI FOOD \& \\ BEVERAGES BOGOR
}

\author{
Samsuri ${ }^{1)}$; Sintia Fuji Lestari ${ }^{2}$ ) \\ Program Studi Manajemen, Fakultas Ekonomi, Universitas Djuanda Bogor \\ Email: samsuri.lido@gmail.com; sintiafujil@gmail.com
}

\begin{abstract}
The aims of this research is to determine the impact of practiceISO 9001:2008 (quality management system) to product quality in production departemen PT Futami Food \& Beverages Bogor. Questioner distributed 35 employees. The method in this research user survey method description and verification. The questioner use validity test, reliability test and classic assumption test. Likert scale is used before multiple regressions testing. This is conduct to know the effect of five free variables that is used on one dependent variable. The result shows all indicators expressed validity and reliability, simultaneously with quality management system $\left(X_{1}\right)$, management responsibility $\left(X_{2}\right)$, resource management $\left(X_{3}\right)$, product realization $\left(X_{4}\right)$, and measurement, analyze, and improvment $\left(X_{5}\right)$ have an ifluence to product quality in production departemen PT Futami Food \& Beverages Bogor (Y). Partially, only management responsibility that gives no effect to product quality in production departemen PT Futami Food \& Beverages Bogor
\end{abstract}

Keywords: Quality Management System ISO 9001:2008 and Product Quality

\begin{abstract}
ABSTRAK
Penelitian ini dimaksudkan untuk mengetahui dampak penerapan ISO 9001:2008 (Sistem Manajemen Mutu) terhadap kualitas produk pada departemen produksi PT Futami Food \& Beverages Bogor. Kuisioner didistribusikan kepada 35 karyawan. Metode yang digunakan pada penelitian ini yaitu metode survey, dengan bentuk penelitian deskriptif dan verifikatif. Kuisioner tersebut menggunakan uji validitas, uji reliabilitas dan uji asumsi klasik. Skala likert digunakan sebelum dilakukan pengujian dengan regresi berganda. Hal ini digunakan untuk melihat pengaruh lima variabel bebas yang digunakan terhadap satu variabel terikat. Hasil penelitian ini berdasarkan hasil dari uji validitas serta uji reliabilitas yang menunjukkan bahwa semua indikator dinyatakan valid dan reliabel. Secara simultan sistem manajemen mutu $\left(\mathrm{X}_{1}\right)$, tanggung jawab manajemen $\left(\mathrm{X}_{2}\right)$, pengelolaan sumber daya $\left(\mathrm{X}_{3}\right)$, realisasi produk $\left(\mathrm{X}_{4}\right)$ dan pengkuran, analisis, dan perbaikan $\left(\mathrm{X}_{5}\right)$, berpengaruh terhadap kualitas produk pada departemen produksi PT Futami Food \& Beverages. Sedangkan secara parsial variabel sistem manajemen mutu, pengelolaan sumber daya, dan pengukuran, analisis dan perbaikan tidak berpengaruh positif dan signifikan terhadap kualitas produk pada departemen produksi PT Futami Food \& Beverages Bogor.
\end{abstract}

Kata kunci : Sistem Manajemen Mutu ISO9001:2008 dan Kualitas Produk Pengaruh Penerapan ISO 9001:2008 terhadap Kualitas Produk pada Departemen ... | 58 


\section{PENDAHULUAN}

Era globalisasi membuat perubahan besar pada pasar industri, baik industri jasa maupun industri manufaktur sehingga menuntut banyak perusahaan/instansi agar lebih maju dan berkembang dengan menggunakan teknologi secara maksimal serta mendorong perusahaan untuk meningkatkan kualitas. Kualitas dapat diartikan sebagai keseluruhan fitur serta karakter dari sebuah produk ataupun jasa untuk bisa memenuhi kebutuhan baik yang terlihat maupun tersamar. Perbedaan penilaian konsumen akan kualitas dan implementasi standar mutu yang berbeda disetiap negara bisa menjadi hambatan terhadap perdagangan. Salah satu hambatannya yaitu dapat berupa penolakan produk yang diakibatkan tidak sesuainya standar yang diatur negara eksportir dan importir. Salah satu upaya perusahaan agar meningkatnya kualitas dan penjamin kualitas adalah dengan melakukan penerapan standar mutu internasional. ISO mengeluarkan standar yang bertaraf internasional agar dapat dipakai oleh semua pihak di seluruh dunia.

ISO 9001 yaitu standar bersifat internasional dimana memuat peraturan sistem manajemen mutu. Dalam penerapan ISO 9001 dapat berupa prosedur standar opersional, Work Instruction (instruksi kerja), Quality Objective (tujuan dan sasaran mutu) dan Quality Program (program mutu). ISO 9001 adalah sistem manajemen mutu hasil perbaikan tahun 2008 yang menentukan persyaratan dan masukan untuk rancangan dan evaluasi dari satu sistem manajemen kualitas yang dimaksudkan untuk menjamin bahwa perusahaan akan memberikan produk (barang atau jasa) yang sesuai dengan persyaratan yang telah ditetapkan (Gaspersz, 2002).

PT Futami Food \& Beverages salah satu perusahaan yang memproduksi minuman teh dalam kemasan telah menerapkan dan berhasil meraih sertifikat ISO 9001:2008 pada tahun 2013 dari PT
SGS Indonesia, akan tetapi perusahaan masih belum sepenuhnya efektif dalam melaksanakan penerapannya. Hal tersebut dibuktikan dengan hasil audit internal mutu yang telah diselenggarakan setiap dua kali dalam setahun. Dari hasil audit tersebut masih ditemukannya ketidaksesuaian seperti tidak terpenuhinya keterampilan operasional yang telah ditetapkan, belum maksimalnya pembersihan area produksi, infrastruktur yang belum diperbaiki, dan seleksi supplier dilakukan setelah menerbitkan order, dan belum konsistennya pengecekan jalur line produksi.

Berdasarkan penilaian penerapan audit internal yang selalu dilakukan secara periodik oleh perusahaan mengenai penerapan ISO 9001:2008 belum terpenuhi secara keseluruhan, dapat diperoleh kesimpulan yaitu ISO 9001:2008 sudah diterapkan tapi dalam penerapannya masih belum optimal. Keadaan yang seperti inilah yang dibutuhkan sebagai bahan evaluasi agar kualitas produk meningkat. Penerapan sistem mutu ISO 9001:2008 dibutuhkan untuk meningkatkan kualitas karena menjadi salah satu aspek penentu keberhasilan perusahaan dalam meraih dan mempertahankan kepercayaan serta memenuhi keinginan pelanggan pada produk yang diproduksi agar bisa bersaing dengan kompetitor.

\section{MATERI DAN METODE}

\section{Sistem Manajemen Mutu ISO9001:2008}

ISO 9001:2008 merupakan suatu standar penjamin mutu yang menentukan aturan dan saran untuk rancangan dan pembandingan dari sistem manajemen mutu, yang dimaksudkan untuk menjamin bahwa instansi akan mengeluarkan produk (barang/jasa) yang memenuhi kriteria sesuai dengan ketentuan. Persyaratan-persyaratan yang ditetapkan dapat berupa kebutuhan tertentu dari konsumen, dimana organisasi tersebut bertanggungjawab menjamin mutu dari produk. Pada sistem manajemen mutu 
terdapat 8 klausul yang menjadi acuan pada sebuah perusahaan, yaitu:

(1) Ruang Lingkup;

(2) Referensi Standar;

(3) Istilah dan definisi;

(4) Sistem Manajemen Mutu;

(5) Tanggung Jawab Manajemen;

(6) Pengelolaan Sumber Daya;

(7) Realisasi Produk;

(8)Pengukuran, Analisis \& Perbaikan.

Secara keseluruhan ISO 9001:2008 tidak terlalu jauh berbeda dengan pendahulunya yaitu ISO 9001:2000. Adapun perbedaaan versi antara ISO 9001:2002 dengan ISO 9001:2008 secara signifikan lebih menegaskan kepada efektivitas proses yang dilakukan pada perusahaan tersebut. Standar ini memuat persyaratan-persyaratan yang harus dipenuhi dalam penerapan sistem manajemen mutu di perusahaan. Persyaratan sistem manajemen mutu yang terdapat di dalam ISO 9001 lebih menekankan pada pendekatan proses. ISO 9001:2008 bukan merupakan standar produk, karena tidak menjelaskan persyaratan-persyaratan yang harus dipenuhi oleh produk. ISO 9001:2008 hanya merupakan standar sistem manajemen mutu, namun diharapkan bahwa produk yang dihasilkan dari suatu sistem manajemen mutu internasional akan bermutu baik (memenuhi standar)

\section{Kualitas Produk}

Kualitas diartikan sebagai nilai atau tingkatan dimana produk/jasa tersebut memenuhi keinginan dari konsumen (Sritomo, 2003). Kualitas produk yaitu karakteristik suatu produk dalam kesanggupannya untuk melengkapi kebutuhan yang telah ditetapkan dan mempunyai sifat laten. Menurut David Garvin dalam Rachma (2014) secara umum dimensi spesifikasi kualitas produk terbagi menjadi kinerja, fitur, kehandalan, kesesuaian, ketahanan, kemampuan pelayanan, keindahan, dan kesan kualitas. 


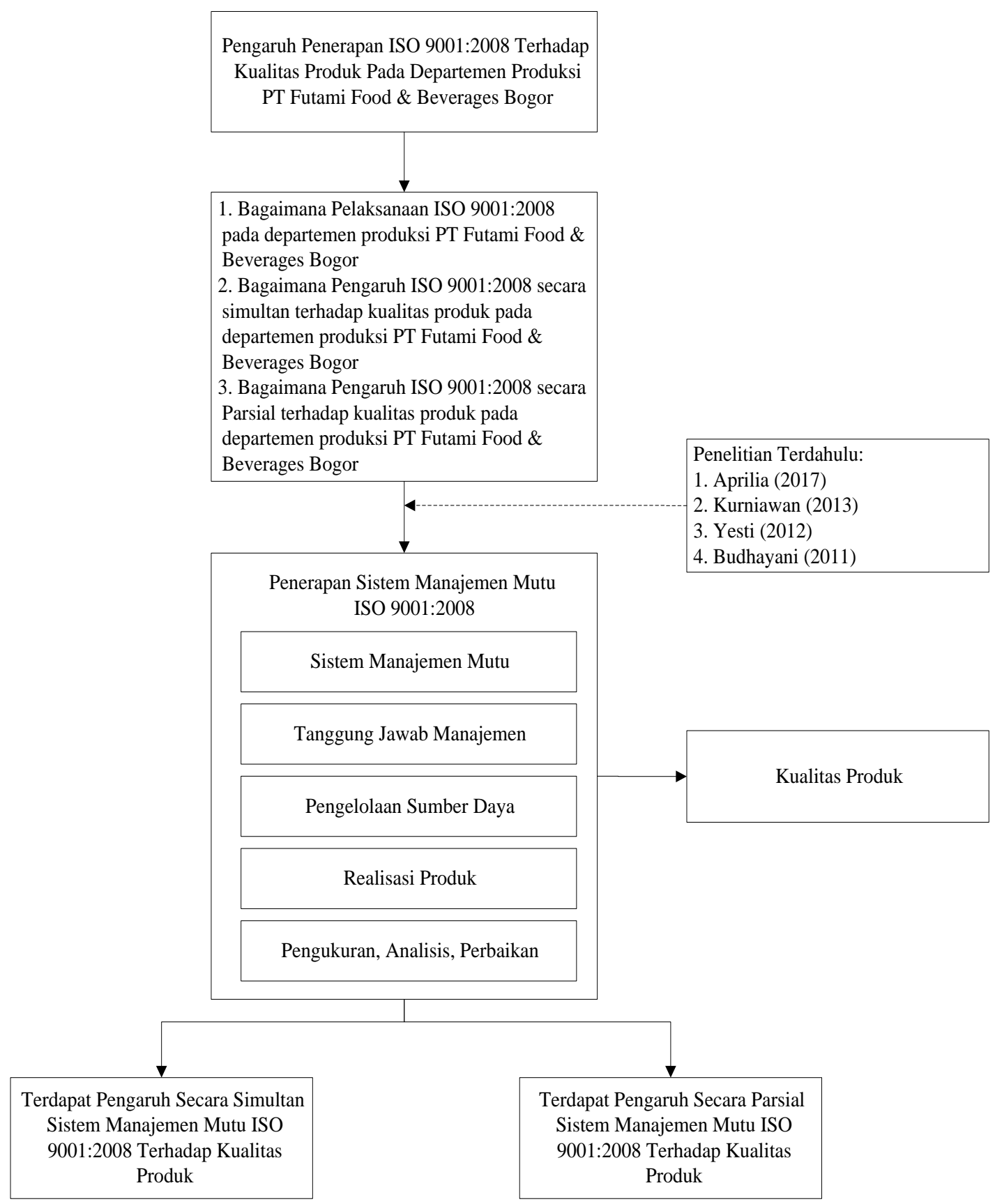

Gambar 1 Kerangka Pemikiran

\section{Metode Penelitian}

Metode yang digunakan yaitu metode deskriptif dan verifikatif. Menurut Sugiyono (2012) metode deskriptif yaitu penelitian yang bertujuan untuk memaparkan variabel mandiri (variabel berdiri sendiri) dengan tidak membuat perbandingan. Sedangkan metode verifikatif adalah sebagai penelitian terhadap populasi/sampel tertentu yang bertujuan mengukur hipotesis yang telah ditentukan. Seluruh karyawan departemen produksi PT Futami Food \& Beverages Bogor menjadi objek dalam penelitian ini. 
Tabel 1. Operasionalisasi Variabel

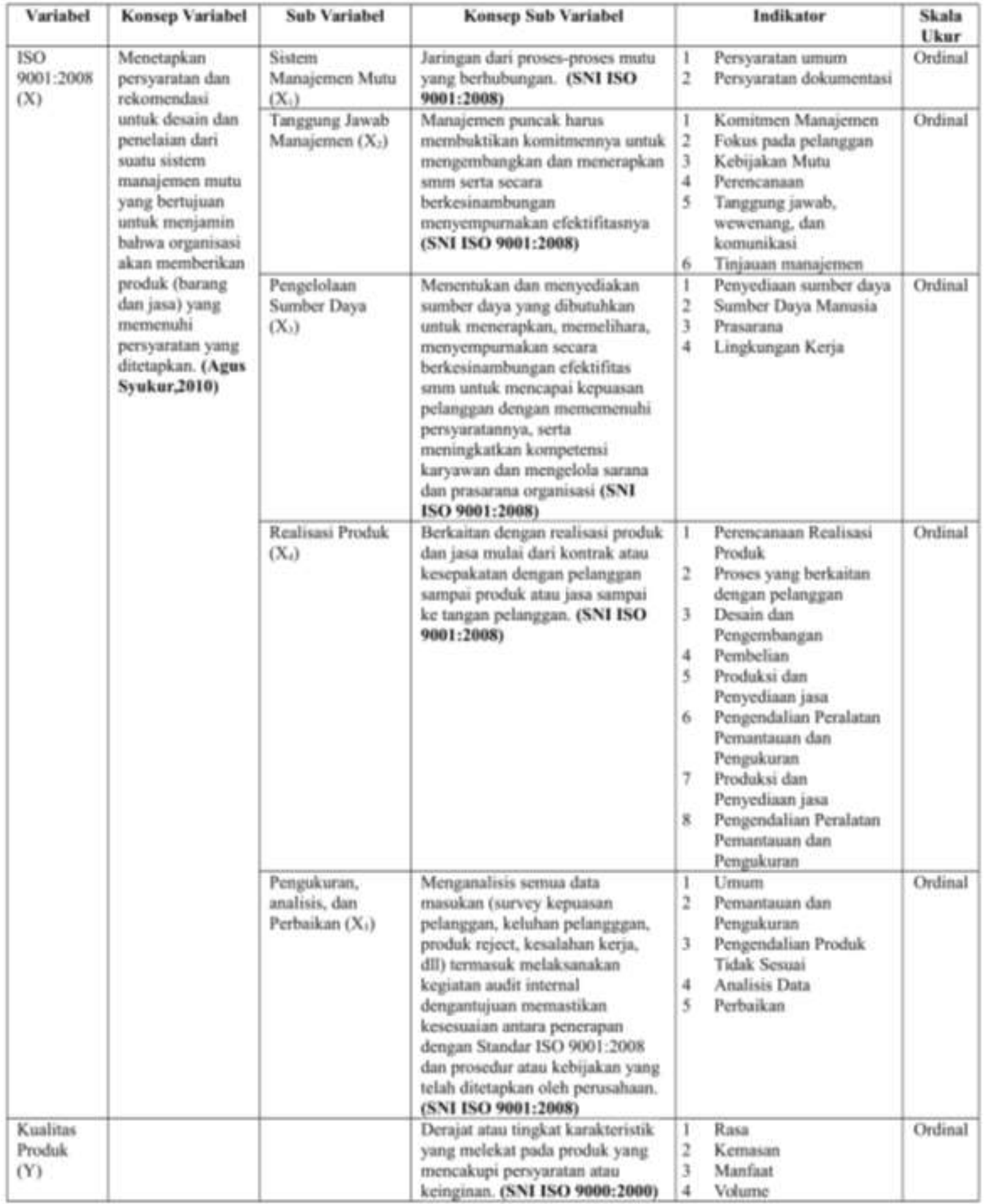

\section{Populasi, Sampel, dan Teknik Pengambilan Sampel}

Pada penelitian ini populasi terdiri dari seluruh karyawan pada departemen produksi PT Futami Food \& Beverages Bogor. Metode penentuan yang digunakan yaitu dengan metode sampling jenuh yaitu teknik penentuan sampel apabila seluruh anggota populasi dipakai sebagai sampel. Maka sampel yang diteliti sebanyak 35 karyawan atau seluruh karyawan departemen produksi PT Futami Food \& Beverages Bogor

\section{Operasionalisasi Variabel}

Variabel yang dianalisis yaitu terdiri dari variabel independen yaitu Sistem 
Manajemen Mutu ISO 9001:2008 (X) yang memiliki sub variabel: sistem manajemen mutu $\left(\mathrm{X}_{1}\right)$, tanggung jawab manajemen $\left(\mathrm{X}_{2}\right)$, pengelolaan sumber daya $\left(\mathrm{X}_{3}\right)$, realisasi produk $\left(\mathrm{X}_{4}\right)$, serta pengukuran analisis dan perbaikan $\left(\mathrm{X}_{5}\right)$. Sedangkan untuk varibel dependennya adalah kualitas produk (Y). Dapat dilihat secara rinci pada tabel 1

\section{Jenis dan Sumber Data}

Data yang dikumpulkan berupa data primer dan sekunder. Prosedur pengumpulan data dilakukan dengan penelitian kepustakaan dan penelitian lapangan (wawancara, observasi, dan kuesioner). Sebelum pengolahan dan analisis data, hal pertama yang dilakukaan adalah menguji data dengan uji validitas untuk mengukur tingkat kevalidan suatu instrumen. Menurut Sugiyono (2014) semua instrumen disebut valid ketika memiliki nilai koefisien product moment sebesar $0,30(\geq 0,30)$, uji reliabilitas agar instrumen reliabel (dapat dipercaya). Seluruh instrumen dikatakan reliable jika memiliki nilai koefisien alpha (cronbanch alpha) sebesar $0,6(\geq 0,6)$. Serta untuk memenuhi ketentuan statistik yang berdasarkan Ordinary Least Square pada analisis regresi linear berganda yaitu dengan melakukan uji asumsi klasik. Uji validitas dan reliabilitas telah dilakukan pada seluruh butir indikator variabel dependen dan variabel independen dengan hasil pada uji validitas $\geq 0,30$ dan hasil pada uji reliabilitas $\geq 0,6$

\section{Uji Asumsi Klasik}

Pengujian asumsi klasik ini dibutuhkan untuk melihat apakah hasil estimasi regresi yang dilakukan benar-benar bebas dari adanya indikasi heteroskedastisitas, multikolinearitas, dan autokorelasi. Uji normalitas untuk memeriksa apakah dalam model regresi variabel dependen dan variabel independen memiliki distribusi normal atau tidak. Hasil uji normalitas dengan grafik histogram dikatakan normal jika kurva yang terbentuk simetris terhadap mean (U) sedangkan hasil pengujian dengan memakai normal probability plot menghasilkan titik-titik yang tersebar di sekitar garis diagonal serta penyebaran data searah dengan garis diagonal. Uji multikoliniaritas digunakan untuk menguji apakah dalam suatu model regresi ditemukan ada atau tidaknya korelasi antara variabel bebas. Uji heteroskedastisitas bertujuan untuk menguji apakah dalam sebuah model regresi terjadi ketidaksamaan varian atau residual dari satu pengamatan ke pengamatan yang lainnya.

\section{Metode Analisis Data}

Seluruh data yang diterima dari responden maka akan di analisis menggunakan uji statistik. Adapun persamaan yang ditetapkan untuk regresi linear berganda adalah seperti dibawah ini:

$$
\begin{aligned}
& Y=a+b_{1} X_{1}+b_{2} X_{2}+b_{3} X_{3}+b_{4} X_{4} \\
& +b_{5} X_{5}+\varepsilon \\
& \text { Keterangan: } \\
& \mathrm{Y}=\text { Peningkatan mutu } \\
& \mathrm{a} \quad=\text { Koefisien konstanta } \\
& \mathrm{b}_{1}, \mathrm{~b}_{2} . \mathrm{b}_{3} \ldots . .=\text { Koefisien regresi variabel } \\
& \mathrm{X}_{1} \quad=\text { Sistem manajemen mutu } \\
& \mathrm{X}_{2} \quad=\text { Tanggung Jawab } \\
& \text { Manajemen } \\
& \mathrm{X}_{3} \quad=\text { Pengelolaan sumber daya } \\
& \mathrm{X}_{4} \quad=\text { Realisasi produk } \\
& \mathrm{X}_{5} \quad=\text { Pengukuran, analisis, dan } \\
& \text { perbaikan } \\
& \boldsymbol{\varepsilon}=\text { Error, variabel gangguan }
\end{aligned}
$$

\section{Analisis Korelasi Berganda}

Analisis korelasi berganda/multiple correlation untuk mengukur seberapa kuat hubungan antara variabel independen dan variabel dependen (Sugiyono, 2013). Untuk dapat memberikan penafsiran pada korelasi yang ditemukan tersebut besar atau kecil, maka dapat berdasar pada ketentuan Tabel berikut ini: 
Tabel. 2 Interpretasi Terhadap Nilai r Hasil Analisis Korelasi

\begin{tabular}{cc}
\hline Interval Nilai $\boldsymbol{r}$ & Interpretasi \\
\hline $0,00-0,199$ & Sangat Lemah \\
$0,20-0,399$ & Lemah \\
$0,40-0,599$ & Cukup Kuat \\
$0,60-0,799$ & Kuat \\
$0,80-1,000$ & Sangat Kuat \\
\hline
\end{tabular}

Sumber: Sugiyono (2013)

\section{Analisis Koefisien Determinasi}

Menurut Ghozali (2012) koefisien determinasi $\left(\mathrm{R}^{2}\right)$ merupakan alat untuk mengukur seberapa jauh kemampuan model dalam menerangkan variasi variabel dependen. Menurut Duwi Priyatno (2010) untuk menghitung koefisien determinasi dapat menggunakan rumus sebagai berikut:

$$
\mathrm{KD}=\boldsymbol{r}^{2} \times 100 \%
$$

$$
\begin{aligned}
& \text { Keterangan: } \\
& \begin{array}{ll}
\mathrm{KD} \quad=\text { koefisien determinasi } \\
\mathrm{r} \quad=\text { koefisien korelasi }
\end{array}
\end{aligned}
$$

\section{Pengujian Hipotesis}

Untuk mengetahui kebenaran dari perhitungan analisis korelasi, maka diperlukan pengujian hipotesis nol $\left(\mathrm{H}_{0}\right)$ dan hipotesis alternatif $(\mathrm{H} \alpha)$. Pengujian ini akan menggunakan Uji F dan Uji t. Pengujian ini akan menggunakan keyakinan (1- $\alpha$ ) sebesar 95\% dan derajat kebebasan sebesar n-6-1 untuk menguji apakah hipotesis diterima atau ditolak.

1) Uji $F$ dengan kriteria bila $F_{\text {hitung }}$ lebih kecil atau sama dengan $F_{\text {tabel }}\left(F_{\text {hitung }} \leq\right.$ $\mathrm{F}_{\text {tabel }}$, pada $\alpha=0,05$ maka $\mathrm{H}_{0}$ diterima dan $\mathrm{H} \alpha$ ditolak, artinya Sistem Manajemen Mutu ISO 9001:2008 tidak mempunyai pengaruh secara bersamasama terhadap kualitas produk pada departemen produksi PT Futami Food \& Beverages Bogor begitupun sebaliknya

2) Uji $\mathrm{T}$ dengan kriteria bila $t_{\text {hitung }}$ lebih kecil dari atau sama dengan $t_{\text {tabel }}\left(t_{\text {hitung }}\right.$ $\left.\leq \mathrm{t}_{\text {tabel }}\right)$ pada $\alpha=0,05$ maka $\mathrm{H}_{0}$ diterima dan $\mathrm{H} \alpha$ ditolak variable tidak memberikan pengaruh signifikan dan positif maupun sebaliknya.

\section{Hasil dan Pembahasan}

PT Futami Food \& Beverages Bogor adalah perusahaan manufacturing yang memproduksi minuman teh dalam kemasan botol yang didirikan pada tanggal 2 April 2007 dengan pabrik pengolahan yang beralamatkan di Jl. Mayjen H.E. Sukma Km 18. Gang Telkom, Ds. Pasir Muncang Caringin - Bogor 16730. Produk yang dihasilkan adalah Futami 17 Green Tea dengan enam varian rasa yaitu Futami 17 Green Tea Klasik, Madu, Leci, Persik, Melon, dan Less Sugar. Perusahaan ini sudah memiliki Sertifikat Halal dari MUI (Majelis Ulama Indonesia), Hygiene dan Sanitasi Makanan dari BPOM (Badan Pengawasan Obat dan Makanan) serta sertifikat ISO 9001:2008 dan sertifikat ISO 22000:2005 pada tahun 2013 dari PT SGS. Dengan visi, "memberikan nilai bagi kehidupan", dan Misi "bersama kami membangun merek produk makanan dan minuman berkelas dunia", PT Futami Food \& Beverages Bogor berusaha menciptakan produk yang bermanfaat dengan kualitas yang baik bagi kehidupan dan berkomitmen untuk menghasilkan produk yang halal, aman dan berkualitas tinggi melalui penerapan Sistem Jaminan Halal, Manajemen Mutu dan Keamanan Pangan dengan mengedepankan kepuasan pelanggan, mutu sumber daya manusia serta melakukan perbaikan yang berkesinambungan pada setiap aspek. 


\section{Karakteristik Karyawan}

Responden sebagai sampel adalah seluruh karyawan departemen produksi PT Futami Food \& Beverages Bogor yang berjumlah 35 orang karyawan. Sementara itu identitas karyawan dijelaskan berdasarkan usia karyawan, pendidikan terakhir, jabatan pekerjaan, dan waktu lama bekerja.
Kesimpulannya bahwa karyawan departemen produksi adalah berusia 26-30 tahun dengan berpendidikan terakhir SMA/SMK/Sederajat, umumnya dengan jabatan pekerjaan helper dan sudah bekerja selama 5-10 tahun. Hasil rekapitulasi dari jawaban karyawan mengenai penerapan ISO 9001:2008 dan kualitas produk pada departemen produksi, sebagai berikut:

Tabel 3 Rekapitulasi Tanggapan Karyawan

\begin{tabular}{clcc}
\hline No & \multicolumn{1}{c}{ Variabel } & $\begin{array}{c}\text { Skor Nilai Rata- } \\
\text { rata }\end{array}$ & Keterangan \\
\hline 1 & Sistem Manajemen Mutu $\left(\mathrm{X}_{1}\right)$ & 4,43 & Sangat Baik \\
2 & Tanggung Jawab Manajemen $\left(\mathrm{X}_{2}\right)$ & 4,17 & Baik \\
3 & Pengelolaan Sumber Daya $\left(\mathrm{X}_{3}\right)$ & 4,09 & Baik \\
4 & Realisasi Produk $\left(\mathrm{X}_{4}\right)$ & 4,10 & Baik \\
5 & Pengukuran, Analisis dan & 4,19 & Baik \\
& Perbaikan $\left(\mathrm{X}_{5}\right)$ & 3,91 & Baik \\
6 & Kualitas Produk (Y) & & \\
\hline & $\quad$ Rata - Rata & 4,15 & Baik \\
\hline
\end{tabular}

Berdasarkan tabel 2 maka rekapitulasi ratarata penerapan ISO 9001:2008 dan kualitas produk pada departemen produksi adalah sebesar 4,15, dengan nilai tertinggi 4,43 yaitusistemmanajemen mutu dan nilai terendah 3,91 yaitu kualitas produk.

\section{Hasil Estimasi Persamaan Regresi}

Adapun persamaan regresi adalah untuk menunjukkan pengaruh ISO 9001:2008 terhadap kualitas produk pada PT Futami Food \& Beverages Bogor. Adapun hasil perhitungan bentuk hubungan fungsional yaitu:

$$
\begin{gathered}
Y=7,654+0,491 X_{1}-0,175 X_{2}+0,583 X_{3}- \\
0,935 X_{4}+1,018 X_{5}+\varepsilon
\end{gathered}
$$

Persamaan tersebut menunjukkan adanya hubungan kuat antara penerapan ISO 9001:2008 dengan kualitas produk yang diproduksi oleh PT Futami Food \& Beverages Bogor. Hubungan ISO 9001:2008 dengan kualitas produk menunjukkan angka korelasi sebesar 0,774 hal tersebut dapat menggambarkan bahwa semakin baik penerapan ISO 9001:2008 maka kualitas produk pada departemen produksi juga akan meningkat

Besarnya ISO 9001:2008 mempengaruhi kualitas produk secara simultan didapat nilai R Square 0,599 atau sebesar 59,9\%. Besarnya pengaruh variabel ISO 9001:2008 (X) terhadap kualitas produk pada departemen produksi PT Futami Food \& Beverages Bogor (Y) sebesar 59,9\%. Sedangkan sisanya $40,1 \%$ dipengaruhi oleh komponen diluar penelitian seperti proses produksi, bahan baku, dan metode yang digunakan.

\section{Pengujian Secara Simultan (Uji F)}

Pengaruh Penerapan ISO 9001:2008 (X) terhadap kualitas produk pada departemen produksi PT Futami Food \& Beverages Bogor (Y) secara simultan akan diuji hipotesisnya sebagai berikut:

$\mathrm{H}_{0}: \beta \mathrm{i} \leq 0$ : Tidak terdapat pengaruh positif dan signifikan secara simultan ISO 9001:2008 terhadap kualitas produk pada departemen produksi (Y) 
$\mathrm{H} \alpha: \beta \mathrm{i}>0$ : $\quad$ Terdapat pengaruh positif dan signifikan secara simultan ISO 9001:2008 terhadap kualitas produk pada departemen produksi (Y)

Berdasarkan hasil uji $\mathrm{F}$ diketahui nilai $\mathrm{F}_{\text {hitung }}$ adalah 8,662 yang akan dibandingkan dengan $\mathrm{F}_{\text {tabel}}$, untuk mengetahui $\mathrm{F}_{\text {tabel }}$ maka perlu perhitungan menggunakan tingkat signifikasi sebesar $0,05(\alpha=5 \%)$ dengan derajat kebebasan n-k-1 (35-6-1) $=28$. Berdasarkan hasil dari derajat kebebasan maka didapatkan nilai $F_{\text {tabel }}$ sebesar 2,55 sehingga $F_{\text {hitung }}>F_{\text {tabel }}(8,662>2,55)$ dan memiliki nilai signifikansi $0,000<0,5$ berarti $\mathrm{H}_{0}$ ditolak dan $\mathrm{Ha}$ diterima, yang artinya dengan derajat kepercayaan sebesar 95\% variabel independen Sistem Manajemen Mutu ISO 9001:2008 (X) berpengaruh positif dan signifikan secara simultan (bersama-sama) terhadap kualitas produk pada departemen produksi PT Futami Food $\&$ Beverages Bogor.

\section{Pengujian Secara Parsial (Uji T)}

Hasil dari uji t secara parsial yang dilakukan pada setiap variabel independen terhadap kualitas produk yaitu:

1. Hasil perhitungan diperoleh $t_{\text {hitung }}$ variabel sistem manajemen $\left(\mathrm{X}_{1}\right)$ sebesar 2,202 dan nilai tabel untuk $\alpha=0,05$ dengan derajat kebebasan $35-6-1=28$ sebesar 2,048 berarti $t_{\text {hitung }}>t_{\text {tabel }}$ $(2,202>2,048)$. Maka $\mathrm{H}_{0}$ ditolak dan $\mathrm{H} \alpha$ diterima, artinya penerapan sistem manajemen $\left(\mathrm{X}_{1}\right)$ mempunyai pengaruh terhadap kualitas produk pada departemen produksi (Y). Dapat dilihat bahwa dengan kadar kepercayaan 95\% penerapan sistem manajemen mutu secara parsial berperan nyata terhadap kualitas produk pada departemen produksi

2. Pada variabel tanggung jawab manajemen $\left(\mathrm{X}_{2}\right)$ diperoleh thitung sebesar $-1,827$ dan nilai $t_{\text {tabel }}$ untuk $\alpha=0,05$ dengan tingkat kebebasan 35-6-1=28 sebesar 2,048 berarti $t_{\text {hitung }}<\mathrm{t}_{\text {tabel }}(-1,827$ < 2,048). Maka $\mathrm{H}_{0}$ diterima dan $\mathrm{H} \alpha$ ditolak, dapat diartikan penerapan tanggung jawab manajemen $\left(\mathrm{X}_{2}\right)$ tidak mempunyai pengaruh terhadap kualitas prooduk pada departemen produksi (Y). Dapat disimpulkan bahwa dengan derajat kepercayaan $95 \%$ penerapan tanggung jawab manajemen secara parsial tidak berperan nyata terhadap kualitas produk pada departemen produksi

3. Hasil perhitungan didapat $t_{\text {hitung }}$ pada variabel pengelolaan sumber daya $\left(\mathrm{X}_{3}\right)$ sebesar 4,331 dan nilai $t_{\text {tabel }}$ untuk $\alpha=$ 0,05 dengan tingkatan kebebasan 35-6$1=28$ sebesar 2,048 berarti thitung $>t_{\text {tabel }}$ (4,331 > 2,048). Maka $\mathrm{H}_{0}$ ditolak dan $\mathrm{H} \alpha$ diterima, yaitu pengelolaan sumberdaya $\left(\mathrm{X}_{3}\right)$ mempunyai pengaruh terhadap kualitas produk pada departemen produksi (Y). Dapat dilihat bahwa dengan ambang kepercayaan 95\% penerapan pengelolaan sumber daya secara parsial berperan nyata terhadap kualitas produk pada departemen produksi

4. Hasil perhitungan diperoleh $t_{\text {hitung }}$ pada variabel realisasi produk $\left(\mathrm{X}_{4}\right)$ sebesar 5,022 dan nilai $t_{\text {tabel }}$ untuk $\alpha=0,05$ dengan angka kebebasan 35-6-1 = 28 sebesar 2,048 berarti thitung $>\mathrm{t}_{\text {tabel }}(-5,022$ $>-2,048)$. Maka $\mathrm{H}_{0}$ diterima dan $\mathrm{H} \alpha$ ditolak, artinya penerapan realiasi produk $\left(\mathrm{X}_{4}\right)$ mempunyai pengaruh terhadap kualitas produk pada departemen produksi (Y). Dapat disimpulkan bahwa dengan taraf kepercayaan $95 \%$ penerapan realisasi produk secara parsial tidak berperan nyata terhadap kualitas produk pada departemen produksi

5. Hasil thitung pada variabel pengukuran, analisis, dan perbaikan $\left(\mathrm{X}_{5}\right)$ sebesar 5,554 dan nilai tabel untuk $\alpha=0,05$ dengan ukuran kebebasan 35-6-1=28 sebesar 2,048 berarti $t_{\text {hitung }}>t_{\text {tabel }}(5,554$ $>$ 2,048). Maka $\mathrm{H}_{0}$ ditolak dan $\mathrm{H \alpha}$ diterima, artinya pengukuran, analisis, dan perbaikan $\left(\mathrm{X}_{5}\right)$ mempunyai pengaruh terhadap kualitas produk pada departemen produksi (Y). Dapat 
menyimpulkan bahwa dengan taraf kepercayaan $95 \%$ penerapan pengukuran, analisis, dan perbaikan secara parsial berperan nyata terhadap kualitas produk pada departemen produksi

\section{Kesimpulan dan Implikasi}

Bersumber pada hasil penelitian mengenai pengaruh penerapan ISO 9001:2008 terhadap kualitas produk pada departemen produksi PT Futami Food \& Beverages Bogor, maka dapat disimpulkan:

1) Tanggapan karyawan departemen produksi terhadap penerapan sistem manajemen sudah dilakukan dengan sangat baik, sedangkan untuk penerapan tanggung jawab manajemen, pengelolaan sumber daya, realisasi produk, dan pengukuran, analisis dan perbaikan sudah dilakukan dengan baik

2) Uji F pada penerapan ISO 9001:2008 secara simultan berpengaruh positif dan signifikan terhadap kualitas produk pada departemen produksi

3) Uji t pada penerapan sistem manajemen mutu, pengelolaan sumber daya, realisasi produk, dan pengukuran, analisis, dan perbaikan berpengaruh terhadap kualitas produk pada departemen produksi. Sedangkan tanggung jawab manajemen tidak mempengaruhi kualitas produk pada departemen produksi

Adapun implikasi yang diberikan adalah:

1) Perlu mempertahankan sertifikat ISO 9001 yang telah diperoleh selama ini serta segera melakukan transisi ISO 9001:2008 dengan versi terbaru yaitu ISO 9001:2015 agar sistem manajemen mutu lebih baik dan dapat memenuhi visi serta misi instansi

2) Untuk penelitian selanjutnya dapat menambahkan indikator lain yang berbeda dan lebih spesifik seperti indikator proses produksi, bahan baku, dan metode produksi yang di pakai serta memperluas sampel penelitian agar hasil yang didapatkan lebih mendukung

\section{Ucapan Terima Kasih}

Penulis mengucapkan terima kasih kepada Keluarga Besar Universitas Djuanda Bogor terutama kepada Dosen Fakultas Ekonomi atas bimbingannya dan PT Futami Food \& Beverages Bogor beserta seluruh karyawan atas bantuan informasi, dukungan sebagai rekan kerja yang sangat baik, dan data yang diberikan.

\section{DAFTAR PUSTAKA}

Akdon dan Riduwan. 2005. Rumus dan Data dalam Aplikasi Statistika, Alfabeta. Bandung.

Aprilia, Selviana Ernayanti. 2017. Pengaruh Penerapan Sistem Manajemen Pangan ISO 22000:2005 Terhadap Kualitas Produk Pangan Pada Departemen Produksi Noodle PT Jakarana Tama Food Industry (Factory) Bogor. Universitas Djuanda, Bogor.

Arikunto, Suharsimi. 2010. Prosedur Penelitian Suatu Pendekatan Praktik. PT Rineka Cipta. Jakarta

Assauri, Sofjan. 2004. Manajemen Produksi dan Operasi. Lembaga Penerbit Fakultas Ekonomi Universitas Indonesia. Jakarta.

Budhayani, Niken Wahyu. 2011. Pengaruh Penerapan SMM ISO 9001:2008 terhadap Kinerja Organisasi PT CG Power System Indonesia, Cileungsi, Bogor. Institut Pertanian Bogor, Bogor http://repository.ipb.ac.id/handle/1234 56789/51988. diakses tanggal 12 Desember 2017.

Daryanto. 2012. Manajemen Produksi. Satu Nusa. Bandung.

Djatmiko, B. Junaedi. 2011. Manajemen Mutu ISO 9001. Stembi Bussiness School. Bandung.

Evans, Lindsay. 2007.Pengantar Six Sigma An Introduction To Six Sigma And Process Improvement. Salemba Empat. Jakarta. 
Gaspersz, Vincent. 2002. Pedoman Implementasi Program Six Sigma Terintegrasi dengan ISO 9001:2000 $M B N Q A$ dan HCCP. PT Gramedia Pustaka Utama. Jakarta. 2005. ISO 9001:2000 and Continual Quality Improvement. PT Gramedia Pustaka Utama. Jakarta 2013. Aplikasi Analisis Multivariate dengan Program IBM SPSS 21 Update PLS Regresi. Badan Penerbit Universitas Diponegoro. Semarang

Gujarati, Damodar. 2006. Dasar-Dasar Ekonometrika. Erlangga. Jakarta .2012.Dasar-dasar Ekonometrika, Terjemahan Mangunsong, R.C.Buku 2, Edisi 5. Salemba Empat. Jakarta

Hamidi. 2005. Metode Penelitian Kualitatif: Aplikasi Praktis Pembuatan Proposal Dan Laporan Penelitian. UMM PRESS. Malang

Heizer, Jay dan Barry Render. 2006. Manajemen Operasi, Edisi 7. Salemba Empat. Jakarta.

2009.

Manajemen Operasi, Buku 1 Edisi 9. Salemba Empat. Jakarta. 2008. Manajemen Produksi dan Operasi, Edisi Revisi. Lembaga Penerbit Fakultas Ekonomi Universitas Indonesia. Jakarta.

Herjanto, Eddy. 2007. Manajemen Operasi, Grasindo. Jakarta.

Kurniawan, Arip. 2013. Pengaruh Penerapan Standar ISO 9001 terhadap Kualitas Produk (Studi Kasus pada PT Trisula Textile Industries), Skripsi Sarjana, Fakultas Ekonomi Universitas Pendidikan Indonesia,

Bandung.https://repository.upi.edu/441 2/I/S_PEM_0707640_Title.pdf. diakses tanggal 12 Desember 2017.
Santoso, Singgih. 2010. Statistik Multivariat. PT Elex Media Komputindo. Jakarta.

Stoner, James A.F. 2006. Manajemen, Terjemah: antarikso, dkk. Erlangga. Jakarta.

Sugiyono. 2011. Metode Penelitian Kuantitatif, Kualitatif, dan $R \& D$. Alfabeta. Bandung

$$
\text { 2012.Metode Penelitian }
$$

Kuantitatif, Kualitatif, dan $R \& D$.

Alfabeta. Bandung

2013.Metode Penelitian

Pendidikan Pendekatan Kuantitatif,

Kualitatif, dan $R \& D$. Alfabeta.

Bandung

2014.MetodePenelitianPendidikanPen dekatanKuantitatifdanKualitatifR\&D.

Alfabeta.Bandung

Standar Nasional Indonesia No ISO 9001:2008, IDT, Tentang Sistem Manajemen Mutu - Persyaratan (SNI ISI 9001:2008), Badan Standarisasi Nasional Indonesia, Jakarta

Syukur, Agus. 2010. 5R, ISO 9001:2008 \& Poka Yoke : Strategi Jitu Manajemen Mutu Perusahaan. Kata Buku. Jakarta.

Wignjosoebroto, Sritomo. 2003. Pengendalian Kualitas \& Reliabilitas. Guna Widya. Jakarta.

Yamit, Zulian. 2013. Manajemen Kualitas Produk \& Jasa. Ekonosia. Yogyakarta.

Yesti, Prima Septi. 2012. Pengaruh Implementasi ISO 9001:2008 terhadap Produktivitas Kerja Karyawan PT Intan Pariwara. Institut Pertanian Bogor, Bogor. http://repository.ipb.ac.id/handle/1234 56789/56219. diakses tanggal 12 Desember 2017.

Zulganef. 2008. Metode Penelitian Sosial dan Bisnis. Edisi Pertama. Graha Ilmu. Yogyakarta 